\title{
Genetic engineering for improving quality and productivity of crops
}

\author{
Asis Datta
}

\begin{abstract}
The importance of optimal nutrition for human health and development is well recognised. Adverse environmental conditions, such as drought, flooding, extreme heat and so on, affect crop yields more than pests and diseases. Thus, a major goal of plant scientists is to find ways to maintain high productivity under stress as well as developing crops with enhanced nutritional value. Genetically-modified (GM) crops can prove to be powerful complements to those produced by conventional methods for meeting the worldwide demand for quality foods. Crops developed by genetic engineering can not only be used to enhance yields and nutritional quality but also for increased tolerance to various biotic and abiotic stresses. Although there have been some expressions of concern about biosafety and health hazards associated with GM crops, there is no reason to hesitate in consuming genetically-engineered food crops that have been thoughtfully developed and carefully tested. Integration of modern biotechnology, with conventional agricultural practices in a sustainable manner, can fulfil the goal of attaining food security for present as well as future generations.
\end{abstract}

Keywords: GM crops, Biotic stress, Abiotic stress, Nutritional quality, Shelf life, Biosafety

\section{Background}

Food insecurity and malnutrition are currently among the most serious concerns for human health, causing the loss of countless lives in developing countries. To be healthy, our daily diet must include ample high quality foods with all of the essential nutrients, in addition to foods that provide health benefits beyond basic nutrition. Even maintaining the amount of food per capita what we are getting today will be a mounting job in the future because of the continuing loss of arable lands and the prevalence of unfavourable environmental conditions including drought, salinity, floods, diseases and so on. In order to ensure food security for future generations, the world must produce $50 \%$ to $100 \%$ more food than at present in spite of the predicted adverse environmental conditions [1].

During the mid-20th century's green revolution, the use of agrochemicals and high-yielding crop varieties developed through conventional plant breeding practices led to a significant boost in crop productivity in India. However, conventional plant breeding alone can no longer sustain the ever-rising global food demand. It is the time to promote sustainable agricultural practices for boosting crop productivity with the utmost conservation of all available natural

Correspondence: asis_datta@rediffmail.com

National Institute of Plant Genome Research, New Delhi 110067, India resources. Agricultural biotechnology is proving to be a powerful complement to conventional methods for meeting worldwide demand for quality food. With the help of modern plant biotechnological tools, today we have access to massive gene pools that can be exploited to impart desirable traits in economically important crops. Geneticallymodified (GM) crops can help us to meet the demand for high-yielding, nutritionally-balanced, biotic and abiotic stress tolerant crop varieties [2-7]. While the global area under GM crops continues to expand every year [8], concerns have been expressed regarding unintended and unpredictable pleiotropic effects of these crops on human health and the environment [9]. However, novel foods developed either by conventional or genetic engineering approaches are no different in terms of possible unintended harmful effects on human health and the environment [10]. In fact, the extent of alteration in genomes, from breeding is much more than that for GM crops.

\section{Main text \\ GM crops versus classically-bred crops}

Classically-bred and GM crops are the outcomes of genetic modifications created through different means of gene transfer technology. Both conventional breeding and GM technology may involve changes in the genetic makeup 
of an organism with respect to DNA sequences and the order of genes. However, the amount of genetic changes brought about by the GM technology is small and well defined as compared to classical breeding where thousands of uncharacterised genes of an organism may be involved. Furthermore, GM crops are the outcome of very specific and targeted modification in the genome where the end products such as proteins, metabolites or the phenotype are well characterised. In traditional breeding the genomes of both the parents are mixed together and randomly re-assorted into the genome of the offspring. Thus, undesirable genes can be transferred along with the desirable genes and at the same time some genes may be lost in the offspring. To rectify these problems plant breeders carry out repeated back-crossing to the desirable parent. This is a time-consuming task and may not always be able to separate a tightly linked unsafe gene. For example, potato varieties developed using traditional breeding produce excessive amounts of naturally occurring glycoalkoloids [11]. These glycoalkoloids cause alkaloid poisoning leading to gastrointestinal, circulatory, neurological and dermatological problems. Hybrids of S. tuberosum and S. brevidens produce a toxin demissidine, which is not produced in either parent [12]. Another instance was the conventionallybred insect-resistant high psoralens variety of celery which was found to produce skin rashes in farm workers who were involved in harvesting this crop [13]. Thus, classical (non-GM) breeding methods can have unintended effects and generate potentially hazardous new products. On the other hand, GM technology employs a precise control on the timing and location of gene products resulting in tissue/organ/development/stress-specific expression an outcome not easy to accomplish with classical breeding. Moreover, GM techniques allow introduction of new traits at one time without involving extensive cross-breeding as in the case of classical breeding. From the scientific point of view, foods developed either by conventional breeding or by GM technology can impart the same effects on human health and the environment.

\section{GM crops and food safety}

GM crops produced by introducing genes for improved agronomic performance and/or enhanced nutrition are under commercial cultivation in many countries [8]. The rigour of the food safety consideration is greatly influenced by the source of the DNA used to develop the GM crop. If the DNA is from an edible plant it will make the regulatory process before commercialisation easier and it will also improve consumer acceptance; as, for example, in our laboratory where the Ama1 gene was isolated from the edible crop Amaranthus and used to develop proteinrich GM potato. It was found to be non-allergenic and safe for consumption using the mouse model [6]. Similarly, the gene $O X D C$ (Oxalate decarboxylase) isolated from the edible fungi Collybia velutipes was found to be nontoxic and non-allergenic [14]. When we introduced a single gene encoding C-5 sterol desaturase (FvC5SD) from Collybia velutipes to the tomato, we obtained a crop with multiple beneficial traits, including improved drought tolerance and fungal resistance $[7,15]$. Other strategies include silencing of the host genes instead of addition of a new gene to enhance shelf life of fruits and vegetables [3]. The genes derived from plant viruses can also be considered as safe transgenes as these viruses are not known to be human pathogens. Several virusresistant transgenics harbouring either the coat protein [16] or overexpressing siRNAs [17] have been developed and released for commercial purposes. A well-known example is the GM papaya resistant to papaya ringspot virus (PRSV) [16]. Presently, about $90 \%$ of papaya cultivated in the island of Hawaii is genetically engineered with a coat protein of PRSV. Commercial cultivation of this GM papaya resulted in a considerable increase in papaya production. To date, no conventional or organic method is available to control this rampant virus.

No harmful effects have been documented after several years of extensive cultivation of GM crops in diverse environments and consumption of GM foods by more than a billion humans and by a larger number of animals $[10,18]$. However, it is important that the performance of a GM crop is closely scrutinized for several generations under field conditions and that it must go through rigorous biosafety assessments on a case-by-case basis, before being released for commercial cultivation. Detailed studies should be carried out on various allergenicity and toxicity parameters on laboratory animals. Expressed proteins must be checked for the stability, digestibility, allergenicity and toxicity. Comparative nutritional profiling should be carried out in GM crops.

\section{Use of markers, a biosafety issue in GM crops}

Selectable and scorable marker genes (SMGs) are indispensible for the selection of transformation events for the generation of GM crops. Among the most highly used selectable markers are kanamycin and hygromycin resistance genes. The major biosafety concerns that are raised regarding SMGs relate to their toxicity or allergenicity and the possibility of horizontal gene transfer (HGT) to relevant organisms and pathogens. It has been suggested that transfer of these marker genes to other plants, may result in development of new unwanted weeds. Neomycin phosphotransferase II (NptII) which is the most commonly used selectable marker is most extensively evaluated for biosafety. The protein had been approved by the Food and Drug administration (FDA) in 1994. Studies have shown that NptII is non-toxic and it is not expected to result in increased weediness or invasiveness and it also does not affect the non-target organisms [19-21]. 


\section{Conclusion}

Plant biotechnology has the potential to address various problems in agriculture and society. GM strategies are being employed to minimize yield losses due to various stresses (biotic and abiotic) and are being used extensively for value addition in food crops by enrichment with quality proteins, vitamins, iron, zinc, carotenoids, anthocyanins and so on. Other ongoing efforts include the enhancement of shelf life of fruits and vegetables so as significantly to reduce the post-harvest losses of perishable crops. Fruit crops are also targeted for the production of edible vaccines to combat major diseases. While the global area under GM crops continues to expand every year, no harmful effects of these crops have been documented even after several years of extensive cultivation in diverse environments and widespread human consumption $[10,18]$. Insect resistant $\mathrm{Bt}$ crops and/or herbicide tolerant GM crops which are currently under commercial cultivation have benefited farmers through better insect and weed management, higher yields and reduced chemical pesticide use $[8,10,22,23]$.

Thus, it can be concluded that sustainable integration of conventional agricultural practices with modern biotechnology can enable the achievement of food security for present and future generations. However, it is important that the performance of a GM crop is closely scrutinized for several generations under field conditions and goes through rigorous bio-safety assessments on a case-by-case basis, before being released for commercial cultivation. GM crops are going to be an essential part of our life and the enormous potential of biotechnology must be exploited to the benefit of humankind.

\section{Abbreviations}

DNA: Deoxyribonucleicacid; FDA: Food and drug administration; FvC5SD: C-5 Sterol desaturase; GM: Genetically modified; Nptll: Neomycin phosphotransferase II; OXDC: Oxalate decarboxylase; SMG: Selectable maker genes.

\section{Competing interests}

The author declares that he has no competing interests.

Received: 16 August 2013 Accepted: 7 October 2013

Published: 1 November 2013

References

1. Baulcombe D: Reaping benefits of crop research. Science 2010, 327:761.

2. Datta A: GM crops: dream to bring science to society. Agric Res 2012, 1:95-99.

3. Meli VS, Ghosh S, Prabha TN, Chakraborty N, Chakraborty S, Datta A: Enhancement of fruit shelf life by suppressing $\mathrm{N}$-glycan processing enzymes. Proc Natl Acad Sci U S A 2010, 107:2413-2418.

4. Ghosh S, Meli VK, Kumar A, Thakur A, Chakraborty N, Chakraborty S, Datta A: The $\mathrm{N}$-glycan processing enzymes a-mannosidase and $\beta$-D-1 N acetylhexosaminidase are involved in ripening-associated softening in the non climacteric fruits of capsicum. J Exp Bot 2011, 62:571-582.

5. Chakraborty S, Chakraborty N, Datta A: Increased nutritive value of transgenic potato by expressing a nonallergenic seed albumin gene from Amaranthus hypochondriacus. Proc Natl Acad Sci U S A 2000, 97:3724-3729.

6. Chakraborty S, Chakraborty N, Agrawal L, Ghosh S, Narula K, Shekhar S, Prakash Naik S, Pande PC, Chakrborti SK, Datta A: Next generation protein rich potato by expressing a seed protein gene $A m A 1$ as a result of proteome rebalancing in transgenic tuber. Proc Natl Acad Sci U S A 2010, 41:17533-17538.

7. Kamthan A, Kamthan M, Azam M, Chakraborty N, Chakraborty S, Datta A: Expression of a fungal sterol desaturase improves tomato drought tolerance, pathogen resistance and nutritional quality. Sci Rep 2012, 2:951.

8. James C: Global Status of Commercialized Biotech/GM Crops. ISAAA Briefs No. 43. Ithaca, NY: ISAAA; 2011.

9. Dona A, Arvanitoyannis IS: Health risks of genetically modified foods. Crit Rev Food Sci Nutr 2009, 49:164-175.

10. Ronald P: Plant genetics, sustainable agriculture and global food security. Genetics 2011, 188:11-20.

11. Hellenas KE, Branzell C, Johnsson H, Slanina P: High levels of glycoalkaloids in the established swedish potato variety magnum bonum. J Sci Food Agric 1995, 68:249-255

12. Laurila J, Laakso I, Valkonen JPT, Hiltunen R, Pehu E: Formation of parental type and novel alkaloids in somatic hybrids between Solanum brevidens and S. tuberosum. Plant Sci 1996, 118:145-155.

13. Berkley SF, Hightower AW, Beier RC, Fleming DW, Brokopp CD, Ivie GW, Broome CV: Dermatitis in grocery workers associated with high natural concentrations of furanocoumarins in celery. Ann Intern Med 1986, 105:351-355.

14. Kesarwani M, Azam M, Natarajan K, Mehta A, Datta A: Oxalate decarboxylase from Collybia velutipes. Molecular cloning and its overexpression to confer resistance to fungal infection in transgenic tobacco and tomato. J Biol Chem 2000, 275:7230-7238.

15. Kamthan A, Kamthan M, Chakraborty N, Chakraborty S, Datta A: A simple protocol for extraction, derivatization, and analysis of tomato leaf and fruit lipophilic metabolites using GC-MS. Protocol Exchange 2012. doi: 10.1038 /protex. 2012.061.

16. Gonsalves D: Control of papaya ringspot virus in papaya: a case study. Annu Rev Phytopathol 1998, 36:415-437.

17. Bonfim K, Faria JC, Noqueira EO, Mendes EA, Araquo FJ: RNAi mediated resistance to Bean golden mosaic virus in genetically engineered common bean (Phaseolus vulgaris). Mol Plant Microbe Interact 2007, 20:717-726.

18. Park J, McFarlane I, Phipps R, Ceddia G: The impact of the EU regulatory constraint of transgenic crops on farm income. N Biotechnol 2011, 28:396-406

19. Nap JP, Bijvoet J, Stiekema WJ: Biosafety of kanamycin-resistant transgenic plants. Transgenic Res 1992, 1:239-249.

20. Fuchs RL, Ream JE, Hammond BG, Naylor MW, Leimgruber RM, Berberich SA: Safety assessment of the neomycin phosphotransferase II (NPTII) protein. Nat Biotechnol 1993, 11:1543-1547.

21. Petersen W, Umbeck P, Hokanson K, Halsey M: Biosafety considerations for selectable and scorable markers used in cassava (Manihot esculenta Crantz) biotechnology. Environ Biosafety Res 2005, 4:89-102.

22. Chaudhary B, Gaur K: The development and regulation of Bt-brinjal in India. ISAAA Brief No. 38. Ithaca, NY: ISAAA; 2009.

23. Carpenter JE: Peer-reviewed surveys indicate positive impact of commercialized GM crops. Nat Biotechnol 2010, 28:319-321.

doi:10.1186/2048-7010-2-15

Cite this article as: Datta: Genetic engineering for improving quality and productivity of crops. Agriculture \& Food Security 2013 2:15.

\section{Submit your next manuscript to BioMed Central and take full advantage of:}

- Convenient online submission

- Thorough peer review

- No space constraints or color figure charges

- Immediate publication on acceptance

- Inclusion in PubMed, CAS, Scopus and Google Scholar

- Research which is freely available for redistribution 